\title{
Sorption of Aqueous Methylene Blue, Cadmium and Lead onto Biochars Derived from Scrap Papers
}

\author{
Xuebin $\mathrm{Xu}^{1}$, Xin $\mathrm{Hu}^{2}$, Zhuhong Ding ${ }^{1,3 *}$, Bin Gao ${ }^{3 * *}$ \\ ${ }^{1}$ School of Environmental Science \& Engineering, Nanjing Tech University, 30 Puzhu Southern Road, \\ Nanjing 211816, P.R. China \\ ${ }^{2}$ State Key Laboratory of Analytical Chemistry for Life Science, Center of Material Analysis and School of Chemistry \\ and Chemical Engineering, Nanjing University, 22 Hankou Road, Nanjing 210093, P.R. China \\ ${ }^{3}$ Agricultural \& Biological Engineering Department, University of Florida, Gainesville, FL 32611, USA
}

Received: 8 December 2019

Accepted: 7 March 2020

\begin{abstract}
Biochars made from scrap newspaper and book paper (NPBx and BPBx, $\mathrm{x}$ represents pyrolysis temperature, ${ }^{\circ} \mathrm{C}$ ) were characterized and used to remove methylene blue (MB), cadmium(Cd(II)) and lead $(\mathrm{Pb}(\mathrm{II}))$ from water solution. BPBx had higher yield, $\mathrm{C}$ content, and ash content and lower $\mathrm{Ca}$ content than NPBx made at the same temperature. Calcite and pyrophyllite were main minerals in NPBx and BPBx, respectively. Biochars made at higher temperature had higher pHpzc values (6.9 11.0). The sorption kinetics of the three pollutants fit pseudo-second model well $\left(\mathrm{R}^{2}=0.991 \sim 0.999\right)$. NPB300 and NPB450 had the largest Langmuir sorption capacity of about $23 \mathrm{mg} \mathrm{g}^{-1}$ for MB, while BPB600 had the capacity of $19.5 \mathrm{mg} \mathrm{g}^{-1}$. NPB600 had the largest Langmuir sorption capacity of $13.8 \mathrm{mg} \mathrm{g}^{-1}$ for $\mathrm{Cd}(\mathrm{II})$ and $451 \mathrm{mg} \mathrm{g}^{-1}$ for $\mathrm{Pb}(\mathrm{II})$. Column sorption capacities were $13.2 \mathrm{mg} \mathrm{g}^{-1}$ (NPB300) and $9.46 \mathrm{mg} \mathrm{g}^{-1}$ (NPB450) for MB and $7.39 \mathrm{mg} \mathrm{g}^{-1}$ (NPB600) for Cd(II). De-ashed BPBx had greater sorption capacity for $\mathrm{MB}$ than pristine $\mathrm{BPBx}$. Deposition caused by reaction with $\mathrm{CaCO}_{3}$ was the main reason for $\mathrm{Pb}$ (II) sorption by NPB600. Scrap newspaper biochars derived at high temperatures were efficient sorbents for the removal of $\mathrm{Pb}(\mathrm{II})$.
\end{abstract}

Keywords: scrap paper biochar, batch sorption, column sorption, contaminant, precipitation

\section{Introduction}

As a form of pyrogenic carbon, plenty of studies have suggested that biochar has the preponderances of

*e-mail: dzhuhong@njtech.edu.cn

**e-mail: bg55@ufl.edu carbon stabilization [1], renewable feedstock sources [2], relatively low cost [3], renewable energy resources [4], and excellent sorption ability [5]. As a consequence, it generally can be used as a novel, high-efficiency, and economical material for water treatment as well as soil remediation and carbon sequestration $[6,7]$. Therefore, the preparation of biochar may be also a novel and lowcost technology for the recycling and reuse of waste biomass. 
The feedstock of biochar is comparatively farranging [8]. It has been demonstrated that feedstock type (i.e. fiber and mineral content) obviously influence the sorption ability of biochar [9, 10]. Generally, biochar prepared by fiber-rich biomass has higher carbon content and oxygen-containing functional groups compared to its biomass and shows superior affinity to some organic pollutants via hydrophobic interaction or hydrogen-bond interaction [11, 12]. However, mineralrich biochar presents excellent combining capacity to some heavy metal contaminants by precipitation [13]. Hence, some fiber- and mineral-rich waste can be recycled for biochar and its values can be promoted. The main components of waste newspaper and book paper are cellulose, fillers/coating (e.g., calcium carbonate, kaolin, talcum powder, and so on), and adhesives (e.g., polyvinyl alcohol and carboxymethyl cellulose) [14]. In our previous study, mineral-rich waste-art-paper could be pyrolyzed to biochar product and the biochar was effective for $\mathrm{Pb}$ (II) removal from aqueous solution [15]. Therefore, further investigations should be carried out to develop scrap paper-based biochar as low-cost, high-efficient and environment-friendly adsorbent for wastewater treatment. Waste newspaper and book paper need to be deinked when making new paper, which makes the recycling process complicated and increases the cost of recycling. Otherwise, the wastewater and sludge produced from the deinking process may result in environmental pollution and also increase the cost of disposal [16, 17]. Therefore, the pyrolysis of waste newspaper and book to prepare biochar may be an environment-friendly and low-cost way for the preparation of a low-cost and high-efficient adsorbent for wastewater treatment. It is also a novel way for the disposal of waste paper.

Dyes are mainly used for coloring of food products, fabrics, textiles and leather products [18]. Some of them are harmful to human health when they are in excessive amounts [19]. In addition, the global emission of heavy metals has become a serious problem because of the toxicity of these metals toward living organisms [20]. Removal of these contaminants from sewage and wastewater has been a huge challenge for researchers. Biochar as a novel sorbent showed distinguished sorption performance to these pollutions [21]. Although most of the researches put more focus on batch experiment to examine pollution removal by biochar [22], fixed-bed column experiments were also carried on by some researchers [23].

The objective of this work is to develop highefficient and low-cost adsorbents from scrap newspaper and book paper for the removal of aqueous MB, $\mathrm{Cd}(\mathrm{II})$ and $\mathrm{Pb}(\mathrm{II})$. The biochar samples derived from scrap newspaper and book paper rich of cellulose and minerals at 300,450 and $600^{\circ} \mathrm{C}$ were subjected to elemental analyses, pHpzc analyses, $\mathrm{N}_{2}$ adsorptiondesorption analyses, Fourier-Transform Infrared Spectroscopy analyses and X-Ray Diffraction analyses. Sorption efficiency was investigated using batch/column sorption. Sorption mechanisms were discussed based on the sorption kinetics and isotherm sorption together with $\mathrm{pH}$ change and components of biochar.

\section{Materials and Methods}

\section{Chemicals}

Methylene blue (MB) stock solutions (2.0 g/L) were prepared by dissolving methylene blue with ultrapure water $(18.3 \mathrm{M} \Omega * \mathrm{~cm})$ from a Milli-Q Advantage A10 (Millipore, USA). $\mathrm{Cd}(\mathrm{II})$ and $\mathrm{Pb}(\mathrm{II})$ stock solutions $(5.0 \mathrm{~g} / \mathrm{L})$ were prepared by dissolving $\mathrm{Pb}\left(\mathrm{NO}_{3}\right)_{2}$ and $\mathrm{CdCl}_{2} \cdot 2.5 \mathrm{H}_{2} \mathrm{O}$ with the ultrapure water. All the reagents were purchased from Sinopharm Chemical Reagent Co., Ltd (Shanghai, P.R. China) and of analytical pure. All the labware were soaked in dilute nitric acid at least overnight, thoroughly flushed with tap water, and then with ultrapure water.

\section{Production of Biochar}

Scrap newspaper and book paper were collected from waste paper recycling bin and were snipped to fragments (about $2 \mathrm{~cm} \times 5 \mathrm{~cm}$ ) using a scissor as feedstock. The fragments were tightly placed in a quartz tube, and then pyrolyzed in a tube furnace (OTF-1200X, USA) under $\mathrm{N}_{2}$ atmosphere (10 psi). The pyrolysis was programmed to raise the internal biomass chamber temperature to 300,450 , and $600^{\circ} \mathrm{C}$ at a rate of $10^{\circ} \mathrm{C} / \mathrm{min}$ and held at the peak temperature for $2 \mathrm{~h}$ before cooling to room temperature. The obtained biochars were also sieved with 60-mesh and 150 -mesh nylon sieves to obtain 0.106-0.25 mm fraction, marked as NPBx and BPBx (NPB and BPB refer to newspaper biochar and book paper biochar, respectively; " $\mathrm{x}$ " refer to the pyrolysis temperature), and stored in zip-lock polyethylene bags for further investigations. De-ashing of biochars was also performed to make de-ashed biochars to investigate the contribution of organic component in pristine biochar on the sorption

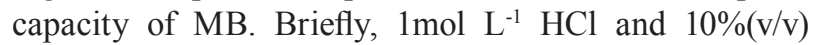
$\mathrm{HF}$ were add to react with $10 \mathrm{~g}$ biochar sample in a polytetrafluoroethylene beaker for $24 \mathrm{~h}$, then the supernatant was discarded after centrifugation. After being subjected to another two cycles of the reaction mentioned above, the residue was washed in a column for continuously waterlogged leaching with tap water and then distilled water. The washed residue was dried at $70^{\circ} \mathrm{C}$ in an oven to gain de-ashed biochar sample.

\section{Characterization}

Yield of biochar samples was calculated by mass difference of dry feedstock and the resultant product (biochar). Contents of $\mathrm{C}, \mathrm{H}$ and $\mathrm{N}$ in biochar samples was determined using a CHN Elemental Analyzer (Carlo-Erba NA-1500). Mineral elements' content was 
analyzed with an inductively coupled plasma optical emission spectrometer (ICP-OES, PerkinElmer Optima $5300 \mathrm{DV}$, USA) after ashing at $450^{\circ} \mathrm{C}$ for $4 \mathrm{~h}$ and aqua regia digestion. Points of zero charge (pHPZC) of the samples were measured by modified $\mathrm{pH}$ drift method $[24,25]$. 0.200g biochar samples were degassed for $2 \mathrm{~h}$ under the temperature of $200^{\circ} \mathrm{C}$, and then specific surface area of biochar samples was measured with a surface area analyzer (BET, ASAP2020, Micromeritics, Ltd., USA). Infrared spectrogram of biochar samples was measured by a Fourier transform infrared spectrometer (NEXUS870, NICOLET, USA) for characterizing the functional groups presented in the pristine and exhausted biochar. X-ray diffraction analysis for the samples was carried out with a powder X-ray diffraction photometer (XRD, CAD4/PC, Enraf Noius, NED).

\section{Bath Sorption Experiments}

In the batch experiment, $0.05 \mathrm{~g}$ biochar sample was mixed with $25 \mathrm{~mL} \mathrm{MB}, \mathrm{Cd}(\mathrm{II})$ or $\mathrm{Pb}$ (II) solutions in $50-\mathrm{mL}$ plastic centrifuge tube. For the kinetics test, initial concentrations of $\mathrm{MB}$ and $\mathrm{Cd}(\mathrm{II})$ solutions were set up according to the pre-experiments and were set as 50 and $30 \mathrm{mg} / \mathrm{L}$, respectively. Initial concentrations of $\mathrm{Pb}$ (II) was set as $30 \mathrm{mg} / \mathrm{L}$ for BPB300, $100 \mathrm{mg} / \mathrm{L}$ for BPB450, BPB600 and NPB300, and $1200 \mathrm{mg} / \mathrm{L}$ for NPB450 and NPB600. For the isotherms test, the initial concentration ranges of sorbates were set as 5-230 $\mathrm{mg} \mathrm{L}^{-1}$ for $\mathrm{MB}$ sorption, 1-44 $\mathrm{mg} \mathrm{L}^{-1}$ for $\mathrm{Cd}(\mathrm{II})$ sorption and $5-200 \mathrm{mg} \mathrm{L}^{-1}$ or $500-2000 \mathrm{mg} \mathrm{L}^{-1}$ for $\mathrm{Pb}$. Initial $\mathrm{pH}$ value of $\mathrm{MB}$ solution was adjusted at $7.0 \pm 0.1$ while $\mathrm{Cd}$ (II) solution and $\mathrm{Pb}$ (II) was adjusted at $5.5 \pm 0.1$ by adding $0.1 \mathrm{~mol} / \mathrm{L}$ (or $0.01 \mathrm{~mol} / \mathrm{L}$ ) $\mathrm{NaOH}$ and $\mathrm{HNO}_{3}$ solutions. The plastic centrifuge tubes were sealed and agitated in a rotary shaker $(120 \mathrm{r} / \mathrm{min})$ at room temperature $\left(25 \pm 2^{\circ} \mathrm{C}\right)$. At the end time of 1-1440 $\mathrm{min}$, the mixtures were immediately centrifuged at $4000 \mathrm{rpm}$ and filtered through $0.45-\mu \mathrm{m}$ pore size nylon membranes. The final $\mathrm{pH}$ values of the filtrate solutions were determined by $\mathrm{pH}$ meter. $\mathrm{Cd}(\mathrm{II}), \mathrm{Pb}$ (II) as well as released ions (i.e. $\mathrm{Ca}(\mathrm{II})$ ) in the filtrates were determined using the ICP-OES. MB in the filtrates was determined by an ultraviolet and visible spectrophotometer at $663 \mathrm{~nm}$ and $\mathrm{pH}$ of 7.0. The adsorbing capacities were calculated as the difference between the initial and final solution concentrations of the sorbates.

\section{Fixed-Bed Column Sorption Experiments}

Fixed-bed column sorption experiments were set up according to the batch sorption experiments and our previous studies $[22,26]$. Specifically, about $1.0 \mathrm{~g}$ of the tested biochar was wet-packed as an interlayer in an acrylic column measuring $1.5 \mathrm{~cm}$ in diameter and $5 \mathrm{~cm}$ in height. At each end of the column, acidcleaned quartz sand (0.5-0.6 mm average size) was used to help distribute the flow. Polypropylene bolting cloth was stowed at juncture of sample and quartz sand to prevent possible loss of biochar sample. A peristaltic pump (Longer Pump, BT100-2J, China) was used at the influent of the column bottom to maintain an upward flow. Column effluent samples were collected every 2 min with a fraction collector (Shanghai Huxi Analysis Instrument Factor Co., Ltd, BS-100A, China) during the experiment and the concentrations of sorbates as well as freed ion (i.e. $\mathrm{Ca}(\mathrm{II})$ ) were analyzed.

\section{Results and Discussion}

\section{Basic Properties and Characterizations of the Biochars}

The yield of NPBx decreased from $38.0 \%$ to $22.7 \%$, and BPBx decreased from $47.0 \%$ to $32.5 \%$ with the increasing pyrolysis temperature from 300 to $600^{\circ} \mathrm{C}$ (Table 1). All the biochar samples were rich in carbon and the content of carbon ranged from $40.6 \mathrm{wt} \%$ to $50.5 \mathrm{wt} \%$. An obvious decline of $\mathrm{H}, \mathrm{O}$, and $\mathrm{N}$ content

Table 1. Yield, specific surface area, elemental composition of C, H, O and N, and ash contents.

\begin{tabular}{|c|c|c|c|c|c|c|c|c|c|}
\hline \multirow{2}{*}{ Biochars } & \multirow{2}{*}{$\begin{array}{c}\mathrm{SA} \\
\left(\mathrm{m}^{2} \cdot \mathrm{g}^{-1}\right)\end{array}$} & \multirow{2}{*}{$\begin{array}{c}\text { Yield } \\
(\%)\end{array}$} & \multicolumn{6}{|c|}{ Elemental composition (wt\%) } & \multirow{2}{*}{$\begin{array}{c}\text { Ash } \\
(w t \%)\end{array}$} \\
\hline & & & $\mathrm{C}$ & $\mathrm{H}$ & $\mathrm{O}^{\mathrm{a}}$ & $\mathrm{N}$ & $\mathrm{H} / \mathrm{C}$ & $(\mathrm{O}+\mathrm{N}) / \mathrm{C}$ & \\
\hline Newspaper & & & 40.0 & 5.63 & 41.3 & 0.138 & 1.69 & 0.777 & 12.9 \\
\hline Book & & & 39.3 & 5.94 & 46.4 & 0.0660 & 1.81 & 0.887 & 8.38 \\
\hline NPB300 & 5.05 & 38.0 & 42.9 & 2.90 & 25.1 & 0.180 & 0.811 & 0.442 & 28.9 \\
\hline NPB450 & 82.3 & 23.7 & 40.6 & 1.97 & 11.7 & 0.080 & 0.583 & 0.219 & 45.7 \\
\hline NPB600 & 225 & 22.7 & 43.6 & 1.50 & 11.8 & 0.050 & 0.413 & 0.204 & 43.0 \\
\hline ВРВ300 & 4.60 & 47.0 & 50.5 & 3.66 & 4.54 & 0.380 & 0.869 & 0.074 & 40.9 \\
\hline BPB450 & 46.9 & 36.7 & 47.9 & 2.00 & 1.71 & 0.110 & 0.501 & 0.029 & 52.3 \\
\hline ВРВ600 & 142 & 32.5 & 44.8 & 1.51 & 1.03 & 0.060 & 0.405 & 0.018 & 53.6 \\
\hline
\end{tabular}

${ }^{a}$ Calculated by mass difference assumed that the total mass of the samples was made up of the tested components only. 
in biochar was observed with the increasing pyrolysis temperature, which indicated the degradation of organic components. Ratio of $\mathrm{H} / \mathrm{C}$ decreased from 0.811 to 0.413 for NPBx and from 0.869 to 0.405 for BPBx, suggesting the strong carbonization and high aromaticity of the biochars at high pyrolysis temperature, which was consistent with the previous reports [6, 27]. Ratio of $(\mathrm{N}+\mathrm{O}) / \mathrm{C}$ also decreased from 0.442 to 0.204 in NPBx and from 0.074 to 0.018 in $\mathrm{BPBx}$, reflecting a decreased polar-group content with the increasing pyrolysis temperature as the previous reports [28]. Ash content of biochars also increased with the increase of pyrolysis temperature (Table 1). Minerals contents of biochars indicated that NPBx samples were rich in $\mathrm{Ca}$ while $\mathrm{BPBx}$ samples were rich in $\mathrm{Ca}, \mathrm{Mg}$, and $\mathrm{Al}$ (Table $\mathrm{S} 1$ in the supplementary material).

The $\mathrm{pH}_{\mathrm{PZC}}$ of the biochars were estimated by plotting the $\mathrm{pH}_{\text {Initial }}$ against the $\mathrm{pH}_{\text {Final }}$ (Fig. S1a), with the sequence of BPB600 (11.0)>NPB600 (10.8) $>$ NPB450 (10.2)>BPB450 (8.8)>NPB300 (8.3)>BPB300 (6.9). Generally, biochar shows positive surface charges and can attract anions when solution $\mathrm{pH}$ is lower than $\mathrm{pH}_{\mathrm{PZC}}$ of the biochar, while show negative surface charges, favorite adsorption of cations, when solution $\mathrm{pH}$ is higher than $\mathrm{pH}_{\mathrm{PZC}}$ of biochar [29]. According to the International Union of Pure and Applied Chemistry (IUPAC) classification [30], the tested biochars exhibited a typical type II isotherm, which suggests that the biochars were nonporous or macroporous adsorbents (Fig. S1b). The more gradual curvature of isotherm is an indication of a significant amount of overlap of monolayer coverage and the onset of multilayer adsorption [30]. The results show that the specific surface area of the resultant biochars increased with the increasing pyrolysis temperature (Table 1).

The FTIR spectra of the biochar samples in the wavenumber region from 500 to $4000 \mathrm{~cm}^{-1}$ are shown in Fig. S2a). The broadband at about $3396 \mathrm{~cm}^{-1}(\mathrm{O}-\mathrm{H}$ stretching vibrations of hydrogen bonded hydroxyl groups) [31] and serial adsorption at 1610 and 1699 $\mathrm{cm}^{-1}(\mathrm{C}=\mathrm{O}$ stretching vibrations) [32] in the biochars became weaken in biochars prepared at high pyrolysis temperature, which showed a decrease of oxygencontaining functional groups (similar to the result of element content). The infrared absorption band around 876 , and $1429 \mathrm{~cm}^{-1}$ of waste newspaper biochars were assigned to the stretching vibration band of $\mathrm{CO}_{3}^{2-}$ [10]. The XRD spectra of the biochars are shown in Fig. S2b). The strong peak corresponding to calcite $\left(\mathrm{CaCO}_{3}, \mathrm{PDF} \# 05-0586\right)$ at $29.38^{\circ}(d=3.04 \AA)$ in waste newspaper biochars were observed, which further confirmed that the main mineral in waste newspaper biochar was $\mathrm{CaCO}_{3}$. However, the strong peak at $9.51^{\circ}$ $(d=9.29 \AA)$ and $28.53^{\circ}(d=3.13 \AA)$ corresponding to pyrophyllite $\left(\mathrm{Al}_{2} \mathrm{Si}_{4} \mathrm{O}_{10}(\mathrm{OH})_{2}\right.$, $\left.\mathrm{PDF} \# 46-1308\right)$ were observed in waste book paper biochars, suggesting that the main mineral in waste book paper biochar was pyrophyllite.

\section{Batch Sorption Performance}

\section{Sorption Kinetics}

The sorption capabilities of $\mathrm{MB}, \mathrm{Cd}(\mathrm{II})$, and $\mathrm{Pb}$ (II) onto the biochars as a function of time are presented in Fig. 1. For MB sorption, the sorption process was very fast during the first $1.5 \mathrm{~h}$, and then slowed down gradually. Overall, waste newspaper biochars showed
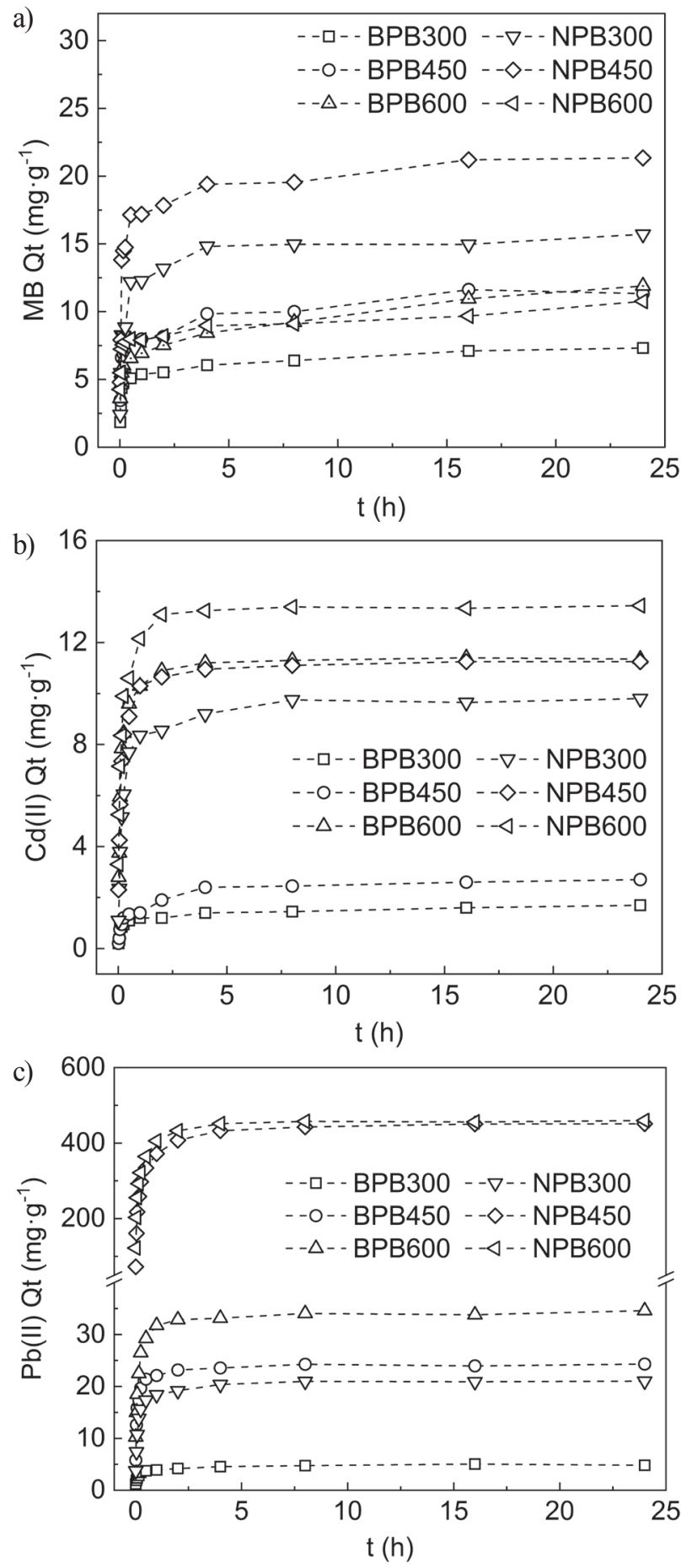

Fig. 1 Sorption kinetics of $\mathrm{MB}$ a), $\mathrm{Cd}(\mathrm{II})$ b) and $\mathrm{Pb}(\mathrm{II}) \mathrm{c}$ ) onto biochars. 
better MB sorption performance than waste book paper biochars. For $\mathrm{Cd}(\mathrm{II})$ and $\mathrm{Pb}(\mathrm{II})$ sorption, the initial sorption rate was rapid within the first $1 \mathrm{~h}$, and then was followed by a slower reaction rate that gradually approached equilibrium within $3 \mathrm{~h}$. In all biochars, NPB450 and NPB600 showed the highest sorption capacity to $\mathrm{Pb}(\mathrm{II})$ (above $400 \mathrm{mg} / \mathrm{g}$ ). Simulations of the pseudo-second-order model fitted well with the experimental data with the correlation coefficients $\left(R^{2}\right)$

a)
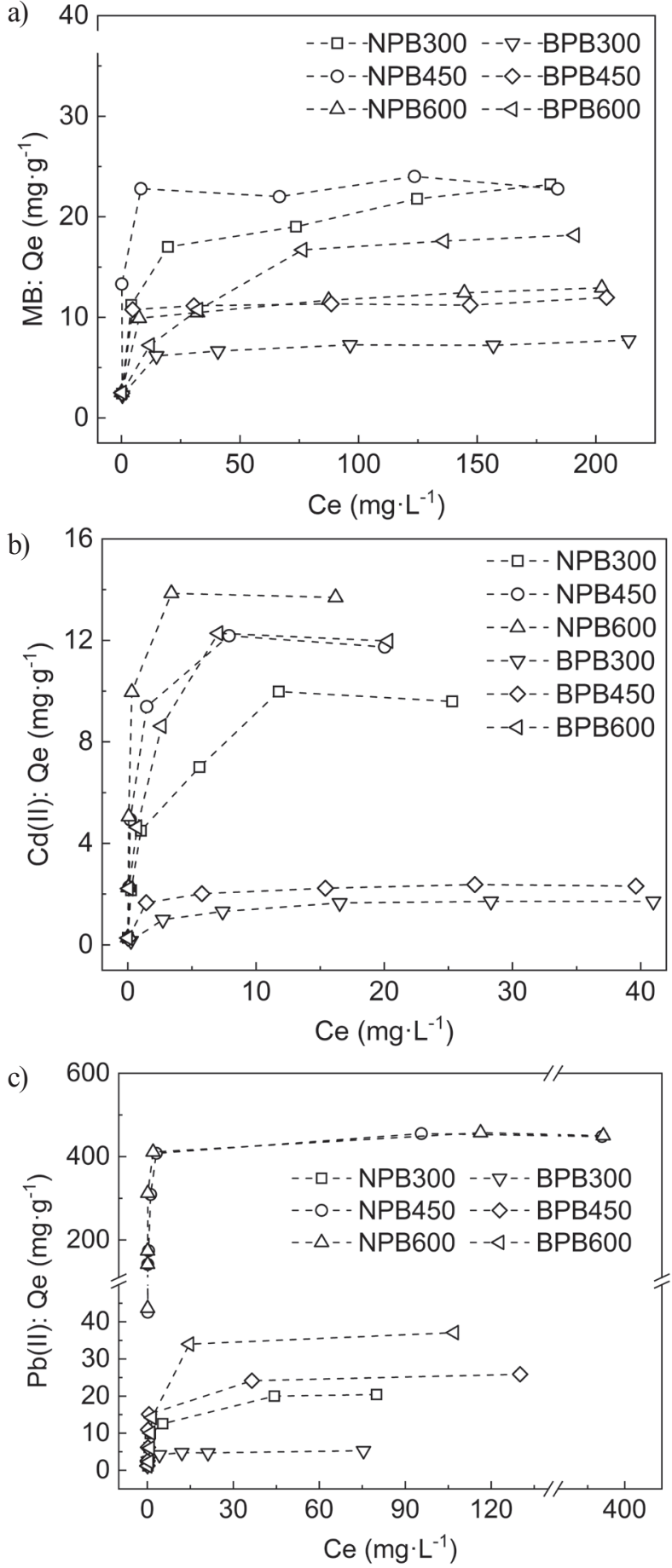

Fig. 2 Sorption isotherms of $\mathrm{MB} \mathrm{a}$ ), $\mathrm{Cd}(\mathrm{II}) \mathrm{b}$ ) and c) $\mathrm{Pb}(\mathrm{II})$ onto biochars. close to one (Table S2), suggesting that $\mathrm{MB}, \mathrm{Cd}(\mathrm{II})$, and $\mathrm{Pb}$ (II) sorption onto resultant biochars could be mainly controlled by binuclear sorption processes [33].

\section{Sorption Isotherms}

Results showed that sorption capabilities of MB, $\mathrm{Cd}(\mathrm{II})$, and $\mathrm{Pb}(\mathrm{II})$ onto the biochar increased obviously and then reached a platform with the increasing equilibrium concentration (Ce) for all the resultant biochar samples (Fig. 2). The sorption performance of $\mathrm{MB}, \mathrm{Cd}(\mathrm{II})$, and $\mathrm{Pb}(\mathrm{II})$ onto NPBx was generally higher than BPBx. In addition, the biochars pyrolyzed at high temperature showed better sorption performance to Cd(II) (13.8 and $12.4 \mathrm{mg} \mathrm{g}^{-1}$ for NPB600 and BPB600, respectively) and $\mathrm{Pb}(\mathrm{II})$ (451 and $36.8 \mathrm{mg} \cdot \mathrm{g}^{-1}$ for NPB600 and BPB600, respectively) than that pyrolyzed at low temperature $\left(\mathrm{Cd}(\mathrm{II}) / \mathrm{Pb}(\mathrm{II}): 10.0 / 21.0 \mathrm{mg} \cdot \mathrm{g}^{-1}\right.$ for NPB300 and $1.83 / 5.32 \mathrm{mg} \cdot \mathrm{g}^{-1}$ for BPB300, respectively) (Table S3). According to correlation coefficients $\left(R^{2}\right)$, the Langmuir model described the sorption data better $\left(\mathrm{R}^{2}=0.982 \sim 0.999\right)$ than the Freundlich model $\left(\mathrm{R}^{2}=0.402 \sim 0.986\right)$, which assumes monolayer sorption on the homogeneous surface (Table S3). The most eminent resultant biochars for sorption of $\mathrm{MB}, \mathrm{Cd}(\mathrm{II})$, and $\mathrm{Pb}$ (II) were NPB300, BPB600, and NPB600, respectively. The Langmuir maximum sorption capacity of NPB600 for $\mathrm{Pb}(\mathrm{II})$ was $451 \mathrm{mg} / \mathrm{g}$, which was much higher than that of other carbon-based sorbents including activated carbon reported in the literature (Table S4).

\section{Column Sorption Performance}

The column breakthrough curves of NPB300 and NPB450 columns, with initial MB concentration of $255 \mathrm{mg} \mathrm{L}^{-1}$ and flow rate of $1.0 \mathrm{~mL} \mathrm{~min}{ }^{-1}$, both showed fast uptake of $\mathrm{MB}$ in initial stages and much slower uptake as saturation was reached at about $60 \mathrm{BV}$ (Fig. 3a). The accumulated sorption amount of MB were $13.2 \mathrm{mg} \mathrm{g}^{-1}$ (NPB300) and $9.46 \mathrm{mg} \mathrm{g}^{-1}$ (NPB450) during the whole sorption process, respectively, which were lower than their Langmuir maximum sorption capacities of batch isotherm sorption (Table S3). The sorption breakthrough curve of $\mathrm{Cd}(\mathrm{II})$ in NPB600 column was conducted with initial $\mathrm{Cd}(\mathrm{II})$ concentration of $167 \mathrm{mg} / \mathrm{L}$ and flow rate of $1.0 \mathrm{~mL} / \mathrm{min}$ (Fig. 3b). An obvious breakthrough point at about $25 \mathrm{BV}$ was observed, and then the saturation stage began at about $60 \mathrm{BV}$. The accumulated sorption amount of $\mathrm{Cd}(\mathrm{II})$ was $7.39 \mathrm{mg} \mathrm{g}^{-1}$ during the whole sorption process, which was lower than its Langmuir maximum sorption capacity of batch isotherm sorption (Table S3), consistent with the previously report [26, 34]. Roh et al. (2015) reported that the column sorption capacity for Cd(II) was slight higher than its Langmuir maximum sorption capacity of batch isotherm sorption at low flow rate and decreased significantly with the increasing flow rate from 0.25 to $1.0 \mathrm{~mL} / \mathrm{min}$ at initial concentration of $20 \mathrm{mg} \mathrm{L}^{-1}$ [35]. 

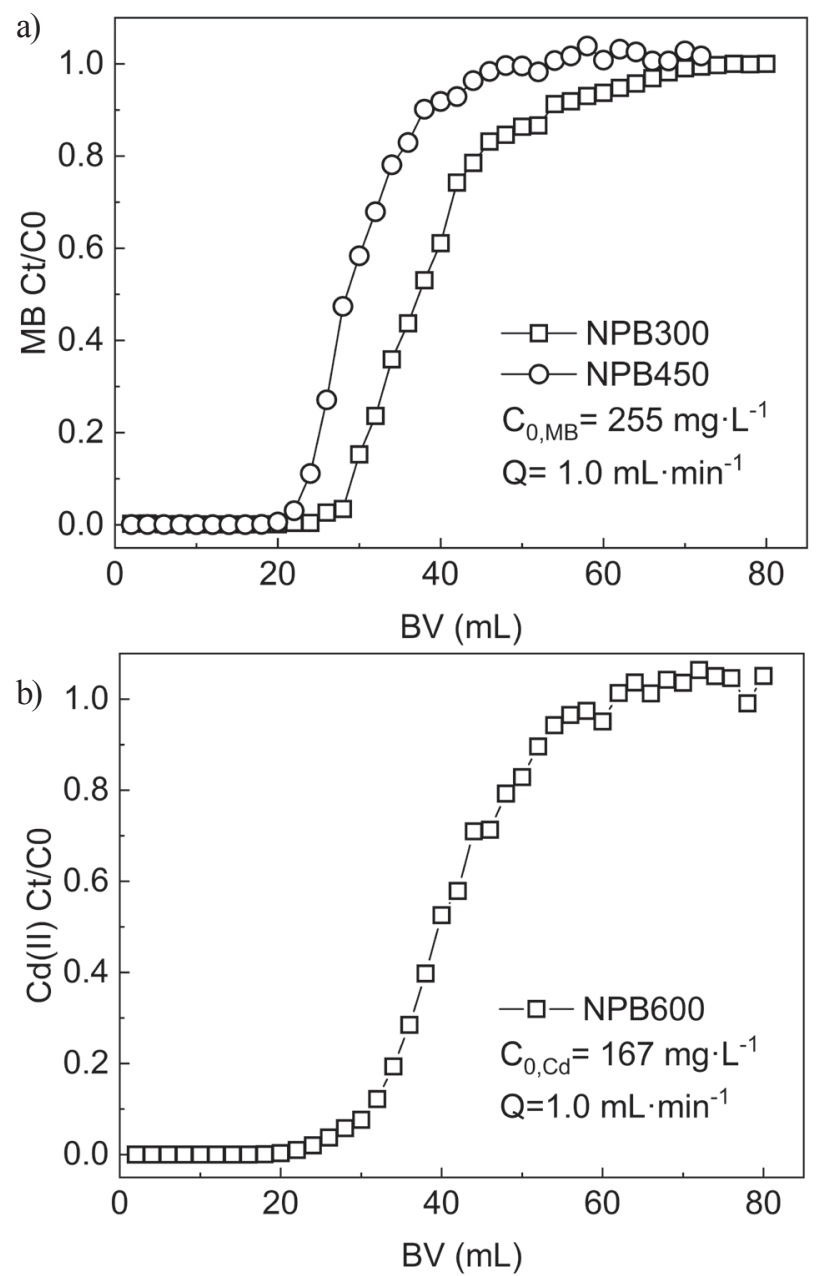

Fig. $3 \mathrm{MB}$ a) and $\mathrm{Cd}(\mathrm{II})$ b) filtration in fixed-bed column packed with biochar.

Therefore, compared to the batch isotherm sorption, the lower sorption capacities of column sorption may be due to short residence time so that fine and ultrafine pores of the biochars might be not involved in the sorption. The parameters such as flow rate may be further optimized to improve sorption capacities. Moreover, physical sorption is generally faster than chemical sorption, so chemical sorption may play more important role on the sorption of $\mathrm{MB}$ and $\mathrm{Cd}$ in this study although they occur concurrently.

\section{Sorption Mechanism}

\section{Effect of Solution $\mathrm{pH}$ and $\mathrm{pHpzc}$ of Biochar}

$\mathrm{pKa}$ of $\mathrm{MB}$ is 2.6 for methylamino and 11.2 for phenothiazinyl at $25^{\circ} \mathrm{C}$, so $\mathrm{MB}$ is a cation in range of solution $\mathrm{pH}$ mentioned above. Biochars show positive charges when the solution $\mathrm{pH}$ is lower than $\mathrm{pHpzc}$ of biochars and negative charges when the $\mathrm{pH}$ above pHpzc [36]. In the sorption of MB by NPBx, final $\mathrm{pH}$ values were 8.08-8.30 (NPB300), 8.28-9.02 (NPB450) and 8.32-8.94 (NPB600) (Fig. S3a). The final $\mathrm{pH}$ values were all lower than $\mathrm{pHpzc}$ values of the three
NPBx biochars (Fig. S3a). It was not electrostatic attraction that contribute to the sorption of $\mathrm{MB}$ as the biochar surface was tending to be positively charged at $\mathrm{pH}$ lower than its pHpzc. In the sorption of $\mathrm{MB}$ by $\mathrm{BPBx}$, final $\mathrm{pH}$ values were higher than the biochar pHpzc in the case of BPB300, while lower in the case of BPB600 and BPB600 (Fig S3a). It is suggested that the electrostatic attraction may contribute in the $\mathrm{MB}$ sorption onto BPB300, but more interactions involved MB sorption onto BPB450 and BPB600. Shi et al. (2014) reported that the main mechanism for the adsorption of MB onto anaerobic granular sludge-derived biochar included electrostatic interaction, ion exchange and surface complexation [37]. Yao et al. (2014) believed that electrostatic attraction was the main mechanism involving the adsorption of $\mathrm{MB}$ onto biochar in clay-biochar composite [38]. Lyu et al. (2018) pointed out that the sorption mechanisms of MB onto ballmilled biochar of different feedstock and pyrolysis temperature were $\pi-\pi$ and electrostatic interactions $(\mathrm{pH}>\mathrm{PZC})$ [39]. So various mechanisms may be involved in the adsorption of MB onto biochar.

In the adsorption of $\mathrm{Cd}(\mathrm{II})$ onto $\mathrm{NPBx}$ and $\mathrm{BPBx}$, final solution $\mathrm{pH}$ values were 7.28-7.75(NPB300), 7.65-8.34(NPB450), 8.08-8.87(NPB600), $\quad 6.84-7.66$ (BPB300), 7.07-7.58 (BPB450), and 7.78-8.28 (BPB600) (Fig. S3b). Similar to the sorption of MB, the tested final $\mathrm{pH}$ values at equilibrium in NPBx treatments were lower than pHpzc values of the biochars, which implied that the sorption of Cd(II) by NPBx was other than electrostatic attraction. Electrostatic attraction may play a role in $\mathrm{Cd}(\mathrm{II})$ sorption by $\mathrm{BPB} 300$ as the final $\mathrm{pH}$ were higher than $\mathrm{pHpzc}$ value of BPB300. In adsorption of $\mathrm{Pb}(\mathrm{II})$, except final $\mathrm{pH}$ values of $\mathrm{BPB} 300$ treatment at low equilibrium $\mathrm{Pb}$ (II) concentration, the rest was all lower than pHpzc values of the adsorbents (Fig. S3c), which implied different sorption mechanism other than electrostatic attraction for $\mathrm{Pb}(\mathrm{II})$.

\section{Effects of Biochar Components}

As $\mathrm{MB}$ is an organic dye, its maximum sorption on de-ashed biochar was also investigated to find possible contribution of de-ashed component and ash component. For the sorption of MB by de-ashed NPBx, the Langmuir maximum sorption capacity was 8.10-11.4 $\mathrm{mg} \cdot \mathrm{g}^{-1}$, much lower than the pristine biochar sorption (Fig. S4 and Table S3). For the sorption of MB by de-ashed BPBx, the Langmuir maximum sorption capacity was $12.2-24.1 \mathrm{mg} \cdot \mathrm{g}^{-1}$, much higher than the pristine biochar (Fig. S4 and Table S3). De-ashed component contributed greater than ash component in MB sorption by BPBx, while less important in MB sorption by NPBx. The different performance may be due to different elements contents, ash contents and minerals contents and types of BPBx and NPBx (Table 1 and Fig. S2b ).

$\mathrm{CaCO}_{3}$ was the main carbonate source of the waste newspaper biochar and the precipitation of heavy 
metals by $\mathrm{CO}_{3}{ }^{2-}$ may contribute to the sorption of the heavy metals [15]. Fig. S5 presents the XRD pattern of pristine, $\mathrm{Cd}(\mathrm{II})$-laden, and $\mathrm{Pb}(\mathrm{II})$-laden biochar. After $\mathrm{Cd}(\mathrm{II})$ sorption, the main mineral in $\mathrm{Cd}(\mathrm{II})$ laden biochar was still $\mathrm{CaCO}_{3}$, as a result of the mediocre sorption performance to $\mathrm{Cd}(\mathrm{II})$. However, the XRD pattern of $\mathrm{Pb}$ (II)-laden biochar presented a series of new peaks which was attributed to cerussite $\left(\mathrm{PbCO}_{3}, \mathrm{PDF} 47-1734\right)$. This results indicated that one of the main mechanisms of $\mathrm{Pb}(\mathrm{II})$ sorption onto the resultant biochar is precipitation. $\mathrm{Ca}^{2+}$ released in the final solution after $\mathrm{Cd}(\mathrm{II})$ and $\mathrm{Pb}(\mathrm{II})$ sorption by NPB600 was recorded (Fig. S6). Molar ratio of sorbed$\mathrm{Cd}(\mathrm{II}) / \mathrm{Pb}(\mathrm{II})$ and released-Ca increased and then then reached constant with the increasing of equilibrium concentrations of $\mathrm{Cd}(\mathrm{II}) / \mathrm{Pb}(\mathrm{II})$ (Fig. S6a, d). The molar ratio of sorbed- $\mathrm{Cd}(\mathrm{II}) / \mathrm{Pb}$ (II) and released-Ca stayed nearly constant between $60 \mathrm{~min}$ and $1440 \mathrm{~min}$ (Fig. S3b, e). It is obvious that $\mathrm{Ca}^{2+}$ released in the whole sorption process. $\mathrm{Ca}^{2+}$ release amount in column adsorption of $\mathrm{Cd}(\mathrm{II})$ (Fig. S6c) was also record. $\mathrm{Ca}^{2+}$ release amount was approximately $55 \mathrm{mg} / \mathrm{L}$ at $20-30 \mathrm{BV}$ where the breakthrough of $\mathrm{Cd}(\mathrm{II})$ began. $\mathrm{Ca}^{2+}$ release amount decreased sharply at $30-50 \mathrm{BV}$ while $\mathrm{Cd}(\mathrm{II})$ concentration in the out fluent increased sharply. Then $\mathrm{Ca}^{2+}$ release amount and $\mathrm{Cd}(\mathrm{II})$ concentration in the out fluent reached nearly platforms after 60BV. These results implied that $\mathrm{Ca}$ may be replaced by $\mathrm{Cd}(\mathrm{II})$ during Cd(II) sorption by NPB600. At the end of the experiment, the accumulated $\mathrm{Cd}(\mathrm{II})$ adsorbed and $\mathrm{Ca}$ (II) released were $0.0658 \mathrm{mmol}$ and $0.0554 \mathrm{mmol}$, respectively, with the $\mathrm{Cd} / \mathrm{Ca}$ molar ratio of 1.19 , which was close to that at maximum adsorption of $\mathrm{Cd}(\mathrm{II})$ in batch experiment. The ratios were all larger than 1, suggesting there may be specific sorption process other than reaction with $\mathrm{CaCO}_{3}$. In the research of Zhang et $\mathrm{al}, \mathrm{Cd}$ was adsorbed mainly due to $\mathrm{Cd}-\pi$ interaction [40]. However, $\mathrm{CaCO}_{3}$ might contribute to the sorption of $\mathrm{Cd}(\mathrm{II})$ in some extent, which was implied from the breakthrough curve of $\mathrm{Cd}(\mathrm{II})$ and release curve of $\mathrm{Ca}^{2+}$. Ion exchange may be another mechanism of $\mathrm{Pb}$ (II)/ $\mathrm{Cd}(\mathrm{II})$ sorption onto the resultant biochars.

\section{Conclusion}

Biochars made from scrap newspaper and book paper had different element contents, ash contents and mineral types, which may result in different sorption mechanisms. Biochars made at higher temperature had higher pHpzc values. After $4 \mathrm{~h}$, the kinetics of the sorption of $\mathrm{MB}, \mathrm{Cd}(\mathrm{II})$ and $\mathrm{Pb}(\mathrm{II})$ all nearly reached equilibrium and the data fit pseudo-second order model well. Newspaper biochar had better sorption performance for the three pollutants than book biochar made at the same temperature. Ash component and de-ashed component contributed differently in BPBx sorption and NPBx sorption of MB. Electrostatic attraction, ion exchange, surface complexation might be involved in the sorption process of $\mathrm{MB}$ onto the resultant biochars. Surface precipitation, ion exchange, complexation/coordination with surface functional groups and $\pi$ electrons were the possible mechanisms of $\mathrm{Cd}(\mathrm{II})$ sorption onto the resultant biochars. Precipitation caused by reaction with $\mathrm{CaCO}_{3}$ and ion exchange were the main reason for $\mathrm{Pb}$ (II) sorption by NPB600, and NPB600 and NPB450 were efficient sorbents for removal of $\mathrm{Pb}(\mathrm{II})$. Therefore, pyrolysis of scrap paper to prepare high-efficient and low-cost adsorbents at higher pyrolysis temperatures $\left(450-600^{\circ} \mathrm{C}\right)$ is a novel and reusing way for the disposal of scrap paper.

\section{Acknowledgements}

The work was supported by the National Key R\&D Program of China (No. 2018YFC1800600), the National Natural Science Foundation of China (No. 21677075), and the Project of International Cooperation and Exchange of Nanjing Tech University (2017-2019). Ding Z. also thanks for the support of China Scholarship Council (CSC201808320034).

\section{Conflict of Interest}

The authors declare no conflict of interest.

\section{Reference}

1. WOOLF D., AMONETTE J.E., STREET-PERROTT F.A., LEHMANN J., JOSEPH S. Sustainable biochar to mitigate global climate change. Nature Communications 1, 2010.

2. XIE T., REDDY K.R., WANG C.W., YARGICOGLU E., SPOKAS K. Characteristics and applications of biochar for environmental remediation: A Review. Critical Reviews in Environmental Science and Technology 45, 939, 2015.

3. MOHAN D., SARSWAT A., OK Y.S., PITTMAN C.U. Organic and inorganic contaminants removal from water with biochar, a renewable, low cost and sustainable adsorbent - A critical review. Bioresource Technology 160, 191, 2014.

4. KAMBO H.S., DUTTA A. A comparative review of biochar and hydrochar in terms of production, physicochemical properties and applications. Renewable \& Sustainable Energy Reviews 45, 359, 2015.

5. AHMAD M., RAJAPAKSHA A.U., LIM J.E., ZHANG M., BOLAN N., MOHAN D., VITHANAGE M., LEE S.S., OK Y.S. Biochar as a sorbent for contaminant management in soil and water: a review. Chemosphere 99, 19, 2014.

6. KEILUWEIT M., NICO P.S., JOHNSON M.G., KLEBER M. Dynamic molecular structure of plant biomassderived black carbon (Biochar). Environmental Science \& Technology 44, 1247, 2010.

7. ZHANG M., GAO B., VARNOOSFADERANI S., HEBARD A., YAO Y., INYANG M. Preparation and characterization of a novel magnetic biochar for arsenic removal. Bioresource Technology 130, 457, 2013.

8. MOHAN D., KUMAR H., SARSWAT A., ALEXANDREFRANCO M., PITTMAN C.U. Cadmium and lead 
remediation using magnetic oak wood and oak bark fast pyrolysis bio-chars. Chemical Engineering Journal 236, 513, 2014.

9. SUN Y.N., GAO B., YAO Y., FANG J.N., ZHANG M., ZHOU Y.M., CHEN H., YANG L.Y. Effects of feedstock type, production method, and pyrolysis temperature on biochar and hydrochar properties. Chemical Engineering Journal 240, 574, 2014.

10. XU X.Y., CAO X.D., ZHAO L. Comparison of rice huskand dairy manure-derived biochars for simultaneously removing heavy metals from aqueous solutions: Role of mineral components in biochars. Chemosphere 92, 955, 2013.

11. FANG Q.L., CHEN B.L., LIN Y.J., GUAN Y.T. Aromatic and Hydrophobic Surfaces of Wood-derived Biochar Enhance Perchlorate Adsorption via Hydrogen Bonding to Oxygen-containing Organic Groups. Environmental Science \& Technology 48, 279, 2014.

12. SUN K., KANG M.J., ZHANG Z.Y., JIN J., WANG Z.Y., PAN Z.Z., XU D.Y., WU F.C., XING B.S. Impact of deashing treatment on biochar structural properties and potential sorption mechanisms of phenanthrene. Environmental Science \& Technology 47, 11473, 2013.

13. INYANG M.I., GAO B., YAO Y., XUE Y., ZIMMERMAN A., MOSA A., PULLAMMANAPPALLIL P., OK Y.S., CAO X. A review of biochar as a low-cost adsorbent for aqueous heavy metal removal. Critical Reviews in Environmental Science and Technology 46, 406, 2015.

14. PERNG Y.S., WANG E.I.C., CHANG C.P. Effect of cobinders for coating on the performance of fluorescent optical brightening agents. Cellulose Chemistry and Technology 49, 209, 2015.

15. XU X., HU X., DING Z., CHEN Y., GAO B. Wasteart-paper biochar as an effective sorbent for recovery of aqueous $\mathrm{Pb}$ (II) into value-added $\mathrm{PbO}$ nanoparticles. Chemical Engineering Journal 308, 863, 2017.

16. SIMSTICH B., BEIMFOHR C., HORN H. Lab scale experiments using a submerged MBR under thermophilic aerobic conditions for the treatment of paper mill deinking wastewater. Bioresource Technology 122, 11, 2012.

17. LAHDENIEMI A., MAKELA M., DAHL O. Drying/ fractionation of deinking sludge with a high-velocity cyclone. Drying Technology 31, 378, 2013.

18. MAHMOUD D.K., SALLEH M.A.M., KARIM W.A.W.A., IDRIS A., ABIDIN Z.Z. Batch adsorption of basic dye using acid treated kenaf fibre char: Equilibrium, kinetic and thermodynamic studies. Chemical Engineering Journal 181, 449, 2012.

19. SHI L., ZHANG G., WEI D., YAN T., XUE X., SHI S., WEI Q. Preparation and utilization of anaerobic granular sludge-based biochar for the adsorption of methylene blue from aqueous solutions. Journal of Molecular Liquids 198, 334, 2014.

20. INYANG M., GAO B., YAO Y., XUE Y.W., ZIMMERMAN A.R., PULLAMMANAPPALLIL P., CAO X.D. Removal of heavy metals from aqueous solution by biochars derived from anaerobically digested biomass. Bioresource Technology 110, 50, 2012.

21. KIM W.K., SHIM T., KIM Y.S., HYUN S., RYU C., PARK Y.K., JUNG J. Characterization of cadmium removal from aqueous solution by biochar produced from a giant Miscanthus at different pyrolytic temperatures. Bioresource Technology 138, 266, 2013.

22. HU X., DING Z.H., ZIMMERMAN A.R., WANG S.S., GAO B. Batch and column sorption of arsenic onto iron- impregnated biochar synthesized through hydrolysis. Water Research 68, 206, 2015.

23. HU X., DING Z., ZIMMERMAN A.R., WANG S., GAO B. Batch and column sorption of arsenic onto ironimpregnated biochar synthesized through hydrolysis. Water Res 68, 206, 2015.

24. JIMENEZ-CEDILLO M.J., OLGUIN M.T., FALL C., COLIN-CRUZ A. As(III) and As(V) sorption on ironmodified non-pyrolyzed and pyrolyzed biomass from Petroselinum crispum (parsley). J Environ Manage 117, 242, 2013.

25. FARIA P.C.C., ÓRFÃO J.J.M., PEREIRA M.F.R. Adsorption of anionic and cationic dyes on activated carbons with different surface chemistries. Water Research 38, 2043, 2004

26. DING Z., HU X., WAN Y., WANG S., GAO B. Removal of lead, copper, cadmium, zinc, and nickel from aqueous solutions by alkali-modified biochar: Batch and column tests. Journal of Industrial and Engineering Chemistry 33, 239, 2016

27. BOGUSZ A., OLESZCZUK P., DOBROWOLSKI R. Application of laboratory prepared and commercially available biochars to adsorption of cadmium, copper and zinc ions from water. Bioresource Technology 196, 540, 2015.

28. CHEN Z., CHEN B., CHIOU C.T. Fast and slow rates of naphthalene sorption to biochars produced at different temperatures. Environmental Science \& Technology 46, 11104, 2012.

29. TAN X., LIU Y., ZENG G., XIN W., HU X., GU Y., YANG Z. Application of biochar for the removal of pollutants from aqueous solutions. Chemosphere 125, 70, 2015.

30. THOMMES M., KANEKO K., NEIMARK A.V., OLIVIER J.P., RODRIGUEZREINOSO F., ROUQUEROL J., SING K.S.W. Physisorption of gases, with special reference to the evaluation of surface area and pore size distribution (IUPAC Technical Report). Pure \& Applied Chemistry 87, 25, 2015.

31. DARBY I., XU C.Y., WALLACE H.M., JOSEPH S., PACE B., BAI S.H. Short-term dynamics of carbon and nitrogen using compost, compost-biochar mixture and organo-mineral biochar. Environmental Science \& Pollution Research 23, 11267, 2016.

32. MUBARIK S., SAEED A., ATHAR M.M., IQBAL M. Characterization and mechanism of the adsorptive removal of 2,4,6-trichlorophenol by biochar prepared from sugarcane baggase. Journal of Industrial \& Engineering Chemistry 33, 115, 2015.

33. YAO Y., GAO B., INYANG M., ZIMMERMAN A.R., CAO X.D., PULLAMMANAPPALLIL P., YANG L.Y. Removal of phosphate from aqueous solution by biochar derived from anaerobically digested sugar beet tailings. Journal of Hazardous Materials 190, 501, 2011.

34. WAN S., WU J., ZHOU S., WANG R., GAO B., HE F. Enhanced lead and cadmium removal using biocharsupported hydrated manganese oxide (HMO) nanoparticles: Behavior and mechanism. Sci Total Environ 616-617, 1298, 2018.

35. ROH H., YU M.-R., YAKKALA K., KODURU J.R., YANG J.-K., CHANG Y.-Y. Removal studies of Cd(II) and explosive compounds using buffalo weed biochar-alginate beads. Journal of Industrial and Engineering Chemistry 26, 226, 2015.

36. TAN X.F., LIU Y.G., ZENG G.M., WANG X., HU X.J., GU Y.L., YANG Z.Z. Application of biochar for the removal 
of pollutants from aqueous solutions. Chemosphere 125, 70, 2015.

37. SHI L., ZHANG G., WEI D., YAN T., XUE X.D., SHI S.S., WEI Q. Preparation and utilization of anaerobic granular sludge-based biochar for the adsorption of methylene blue from aqueous solutions. J Mol Liq 198, 334, 2014.

38. YAO Y., GAO B., FANG J.N., ZHANG M., CHEN H., ZHOU Y.M., CREAMER A.E., SUN Y.N., YANG L.Y. Characterization and environmental applications of claybiochar composites. Chem Eng J 242, 136, 2014.
39. LYU H.H., GAO B., HE F., ZIMMERMAN A.R., DING C., TANG J.C., CRITTENDEN J.C. Experimental and modeling investigations of ball-milled biochar for the removal of aqueous methylene blue. Chem Eng J 335, 110, 2018.

40. ZHANG C., SHAN B., TANG W., ZHU Y. Comparison of cadmium and lead sorption by Phyllostachys pubescens biochar produced under a low-oxygen pyrolysis atmosphere. Bioresource Technology 238, 352, 2017. 


\title{
Removal of Methylene Blue, Cadmium and Lead from Water Solution with Biochars Pyrolyzed from Scrap Papers
}

\author{
Xuebin $\mathrm{Xu}^{1}$, Xin $\mathrm{Hu}^{2}$, Zhuhong Ding ${ }^{1,3 *}$, Yijun Chen ${ }^{2}$, Bin Gao ${ }^{3 * *}$
}

${ }^{1}$ School of Environmental Science \& Engineering, Nanjing Tech University, 30 Puzhu Southern Road,

Nanjing 211816, P.R. China

${ }^{2}$ State Key Laboratory of Analytical Chemistry for Life Science, Center of Material Analysis and School of Chemistry and Chemical Engineering, 22 Hankou Road, Nanjing University, Nanjing 210093, P.R. China

${ }^{3}$ Agricultural \& Biological Engineering Department, University of Florida, Gainesville, FL 32611, USA

Table S1. Mineral element contents $\left(\mathrm{mg} \cdot \mathrm{g}^{-1}\right)$ of the feedstocks and the resultant biochars.

\begin{tabular}{|c|c|c|c|c|c|c|}
\hline & \multicolumn{6}{|c|}{ Mineral element content $\left(\mathrm{mg} \cdot \mathrm{g}^{-1}\right)$} \\
\hline & $\mathrm{K}$ & $\mathrm{Ca}$ & $\mathrm{Na}$ & $\mathrm{Mg}$ & $\mathrm{Al}$ & $\mathrm{Fe}$ \\
\hline Newspaper & 0.0331 & 2.57 & 0.178 & 0.0950 & 1.83 & 0.0596 \\
\hline Book & 0.0213 & 0.691 & 0.0517 & 0.415 & 0.945 & 0.0443 \\
\hline NPB300 & 0.536 & 62.2 & 3.00 & 2.65 & 11.6 & 4.42 \\
\hline NPB450 & 0.401 & 104 & 4.04 & 4.90 & 17.6 & 1.26 \\
\hline NPB600 & 0.562 & 109 & 4.34 & 4.98 & 22.0 & 1.19 \\
\hline BPB300 & 0.426 & 16.2 & 0.793 & 14.4 & 10.8 & 2.13 \\
\hline BPB450 & 0.248 & 6.68 & 0.371 & 12.8 & 7.39 & 1.23 \\
\hline BPB600 & 0.661 & 12.7 & 0.769 & 28.1 & 16.1 & 2.91 \\
\hline
\end{tabular}

Table S2. Kinetic parameters of the pseudo-second-order and pseudo-first-order models for MB, Cd(II), and Pb(II) sorption onto biochars.

\begin{tabular}{|c|c|c|c|c|c|c|c|}
\hline \multirow{3}{*}{ Sorbates } & \multirow{3}{*}{ Biochar } & \multicolumn{3}{|c|}{$\begin{array}{c}\text { Pseudo-first order kinetics } \\
\ln \left(Q_{e}-Q_{t}\right)=\ln Q_{e}-k_{l} t\end{array}$} & \multicolumn{3}{c|}{$\begin{array}{c}\text { Pseudo-second order kinetics } \\
t / Q_{t}=1 /\left(k_{2} Q_{e}^{2}\right)+t / Q_{e}\end{array}$} \\
\cline { 3 - 9 } & & $\mathrm{Q}_{\mathrm{e}, \mathrm{cal}}$ & $\mathrm{k}_{1}$ & $\mathrm{R}^{2}$ & $Q_{e, \text { cal }}$ & $k_{2}$ & $R^{2}$ \\
\hline \multirow{5}{*}{$\mathrm{MB}$} & $\mathrm{BPB} 300$ & 6.01 & 13.3 & 0.773 & 7.28 & 0.434 & 0.998 \\
\cline { 2 - 9 } & BPB450 & 9.22 & 13.7 & 0.602 & 11.5 & 0.217 & 0.998 \\
\cline { 2 - 9 } & BPB600 & 8.53 & 12.0 & 0.439 & 11.7 & 0.146 & 0.991 \\
\cline { 2 - 9 } & NPB300 & 14.0 & 6.40 & 0.852 & 15.6 & 0.318 & 0.999 \\
\cline { 2 - 9 } & NPB450 & 18.7 & 11.7 & 0.854 & 21.4 & 0.230 & 0.999 \\
\cline { 2 - 9 } & NPB600 & 8.65 & 24.4 & 0.640 & 10.4 & 0.310 & 0.995 \\
\hline
\end{tabular}

*e-mail: dzhuhong@njtech.edu.cn

**e-mail: bg55@ufl.edu 
Table S2. Continued.

\begin{tabular}{|c|c|c|c|c|c|c|c|}
\hline \multirow{5}{*}{} & BPB300 & 1.39 & 6.10 & 0.823 & 1.68 & 1.46 & 0.997 \\
\cline { 2 - 9 } & BPB450 & 2.37 & 1.85 & 0.852 & 2.72 & 0.741 & 0.999 \\
\cline { 2 - 9 } & BPB600 & 10.8 & 8.20 & 0.939 & 11.4 & 1.07 & 0.999 \\
\cline { 2 - 9 } & NPB300 & 9.14 & 4.90 & 0.964 & 9.84 & 0.580 & 0.999 \\
\cline { 2 - 9 } & NPB450 & 10.6 & 7.99 & 0.940 & 11.3 & 0.902 & 0.999 \\
\cline { 2 - 9 } & NPB600 & 12.7 & 8.09 & 0.897 & 13.5 & 0.866 & 0.999 \\
\hline \multirow{5}{*}{ Pb(II) } & BPB300 & 4.41 & 7.91 & 0.852 & 4.90 & 1.41 & 0.999 \\
\cline { 2 - 9 } & BPB450 & 22.8 & 13.2 & 0.917 & 24.3 & 0.566 & 0.999 \\
\cline { 2 - 9 } & BPB600 & 32.4 & 9.53 & 0.891 & 34.5 & 0.306 & 0.999 \\
\cline { 2 - 9 } & NPB300 & 19.7 & 8.04 & 0.947 & 21.1 & 0.434 & 0.999 \\
\cline { 2 - 9 } & NPB450 & 414 & 6.62 & 0.898 & 454 & 0.0147 & 0.999 \\
\cline { 2 - 9 } & NPB600 & 426 & 9.23 & 0.848 & 461 & 0.0230 & 0.999 \\
\hline
\end{tabular}

Where $Q_{e, c a l}$ : equilibrium adsorption capacity calculated by pseudo-first or pseudo-second order kinetics $\left(\mathrm{mg} \cdot \mathrm{g}^{-1}\right) ; k_{l}$ : first-order apparent adsorption rate constants $\left(\mathrm{h}^{-1}\right) ; k_{2}$ : second-order apparent adsorption rate constants $\left(\mathrm{g} \cdot \mathrm{mg}^{-1} \cdot \mathrm{h}^{-1}\right)$.

Table S3. Isotherm parameters for the Langmuir and Freundlich models for $\mathrm{MB}, \mathrm{Cd}(\mathrm{II})$, and $\mathrm{Pb}(\mathrm{II})$ sorption onto biochars.

\begin{tabular}{|c|c|c|c|c|c|c|c|}
\hline \multirow[t]{2}{*}{ Sorbates } & \multirow[t]{2}{*}{ Biochar } & \multicolumn{3}{|c|}{$\begin{array}{c}\text { Langmuir } \\
\mathrm{Ce} / \mathrm{Qe}=1 /\left(\mathrm{K}_{L} Q m\right)+\mathrm{Ce} / \mathrm{Qm}\end{array}$} & \multicolumn{3}{|c|}{$\begin{array}{c}\text { Freundlich } \\
Q e=K_{F} C e^{(I / n)}\end{array}$} \\
\hline & & $Q_{m}$ & $K_{L}$ & $R^{2}$ & $\mathrm{~K}_{\mathrm{F}}$ & $n$ & $R^{2}$ \\
\hline \multirow{6}{*}{ MB } & ВРB300 & 7.69 & 0.230 & 0.998 & 2.98 & 5.15 & 0.929 \\
\hline & BPB450 & 11.8 & 0.523 & 0.998 & 4.62 & 4.77 & 0.765 \\
\hline & ВРB600 & 19.5 & 0.0673 & 0.998 & 3.79 & 3.24 & 0.986 \\
\hline & NPB300 & 23.4 & 0.146 & 0.994 & 5.03 & 3.08 & 0.923 \\
\hline & NPB450 & 23.2 & 0.817 & 0.998 & 8.84 & 4.72 & 0.491 \\
\hline & NPB600 & 13.0 & 0.222 & 0.988 & 4.58 & 4.58 & 0.916 \\
\hline \multirow{6}{*}{$\mathrm{Cd}(\mathrm{II})$} & ВРВ300 & 1.83 & 0.419 & 0.999 & 0.415 & 2.17 & 0.901 \\
\hline & BPB450 & 2.37 & 1.55 & 0.999 & 0.916 & 3.06 & 0.882 \\
\hline & ВРB600 & 12.4 & 1.57 & 0.996 & 4.58 & 2.14 & 0.925 \\
\hline & NPB300 & 10.0 & 1.03 & 0.993 & 3.36 & 2.39 & 0.976 \\
\hline & NPB450 & 12.5 & 1.07 & 0.982 & 4.45 & 2.03 & 0.646 \\
\hline & NPB600 & 13.8 & 8.06 & 0.997 & 8.07 & 2.31 & 0.811 \\
\hline \multirow{6}{*}{$\mathrm{Pb}(\mathrm{II})$} & ВРВ300 & 5.32 & 0.956 & 0.999 & 2.70 & 5.15 & 0.918 \\
\hline & BPB450 & 26.3 & 0.864 & 0.999 & 7.68 & 3.56 & 0.699 \\
\hline & ВРВ600 & 36.8 & 0.286 & 0.999 & 5.75 & 2.29 & 0.824 \\
\hline & NPB300 & 21.0 & 0.434 & 0.997 & 5.05 & 2.18 & 0.777 \\
\hline & NPB450 & 449 & 1.89 & 0.999 & 138 & 3.33 & 0.611 \\
\hline & NPB600 & 451 & 1.85 & 0.999 & 157 & 4.33 & 0.402 \\
\hline
\end{tabular}

Where $Q_{m}$ : maximum adsorption capacity $\left(\mathrm{mg} \mathrm{g}^{-1}\right) ; K_{L}$ : Langmuir constant $\left(\mathrm{L} \mathrm{mg}^{-1}\right) ; R^{2}$ : coefficient of determination; $K_{F}$ : affinity coefficient related to the bonding energy $\left(\mathrm{mg}^{(1-1 / n)} \mathrm{L}^{1 / n} \mathrm{~g}^{-1}\right) ; n$ : the heterogeneity factor which represents the bond distribution. 
Table S4. Comparison of lead sorption capacities of waste newspaper biochar with various biochars in previous studies.

\begin{tabular}{|c|c|c|c|c|}
\hline Biochar & $\begin{array}{c}\mathrm{pH} \\
\text { condition }\end{array}$ & $\begin{array}{l}\text { Sorption } \\
\text { capability }\end{array}$ & Sorption mechanism & References \\
\hline $\begin{array}{c}\text { Phyllostachys pubescens } \\
\text { biochar }\end{array}$ & $5.0 \pm 0.05$ & $67.4 \mathrm{mg} / \mathrm{g}$ & Precipitation & {$[1]$} \\
\hline Sewage sludge biochar & \multirow[b]{2}{*}{$2.0-6.0$} & $44.91 \mathrm{mg} / \mathrm{g}$ & NA & \multirow[b]{2}{*}[2]{} \\
\hline $\begin{array}{l}\text { Magnetic sewage sludge } \\
\text { biochar }\end{array}$ & & $249.00 \mathrm{mg} / \mathrm{g}$ & $\begin{array}{l}\text { Electrostatic attraction, ion exchange, electrostatic surface } \\
\text { complexation, inner-sphere complexation and co-precipi- } \\
\text { tation }\end{array}$ & \\
\hline Celery biochar & 5.0 & $304 \mathrm{mg} / \mathrm{g}$ & Cation exchange, precipitation, and surface complexation & {$[3]$} \\
\hline Banana peel based biochar & $2-7$ & $359 \mathrm{mg} / \mathrm{g}$ & Ions exchange and surface complexation & {$[4]$} \\
\hline $\begin{array}{l}\mathrm{KMnO}_{4} \text { treated hickory } \\
\text { wood biochar }\end{array}$ & $2-7$ & $153.1 \mathrm{mg} / \mathrm{g}$ & $\begin{array}{l}\text { The surface functional groups and } \mathrm{MnOx} \text { particles serve as } \\
\text { the main adsorption sites for } \mathrm{Pb} \text { (II) }\end{array}$ & {$[5]$} \\
\hline Sugar cane bagasse biochar & \multirow{2}{*}{$2-6$} & $86.96 \mathrm{mg} / \mathrm{g}$ & \multirow{2}{*}{$\begin{array}{l}\text { Supposed as a specific ion-exchange mechanism, and sur- } \\
\text { face precipitation of metal ion hydroxides for both biochars }\end{array}$} & \multirow{2}{*}[6]{} \\
\hline orange peel biochar & & $27.86 \mathrm{mg} / \mathrm{g}$ & & \\
\hline Alkali-modified biochar & 5.0 & $53.6 \mathrm{mg} / \mathrm{g}$ & NA & [7] \\
\hline $\begin{array}{l}\text { Functionalized graphene } \\
\left(\mathrm{GNS}^{\mathrm{PF}}\right)\end{array}$ & 5.1 & $406.4 \mathrm{mg} / \mathrm{g}$ & NA & [8] \\
\hline $\begin{array}{l}\text { Activated carbon-alginate } \\
\text { composite material }\end{array}$ & 5 & $15.7 \mathrm{mg} / \mathrm{g}$ & NA & [9] \\
\hline $\begin{array}{l}\text { Lignin-grafted carbon } \\
\text { nanotubes }\end{array}$ & $2-7$ & $221 \mathrm{mg} / \mathrm{g}$ & Complexation & {$[10]$} \\
\hline Waste newspaper biochar & 5.5 & $451 \mathrm{mg} / \mathrm{g}$ & Precipitation & This study \\
\hline
\end{tabular}

NA: not available.

a)

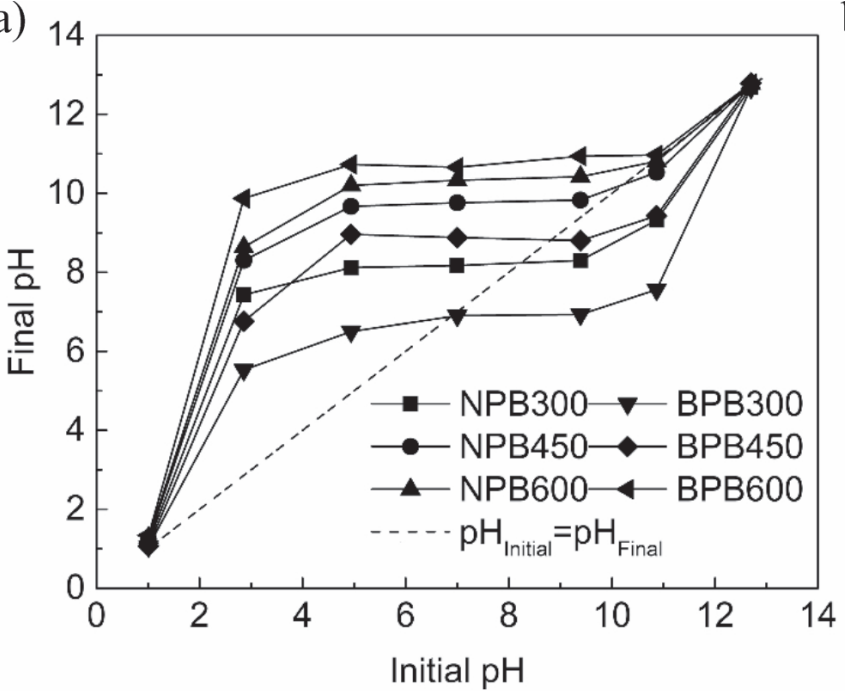

b)

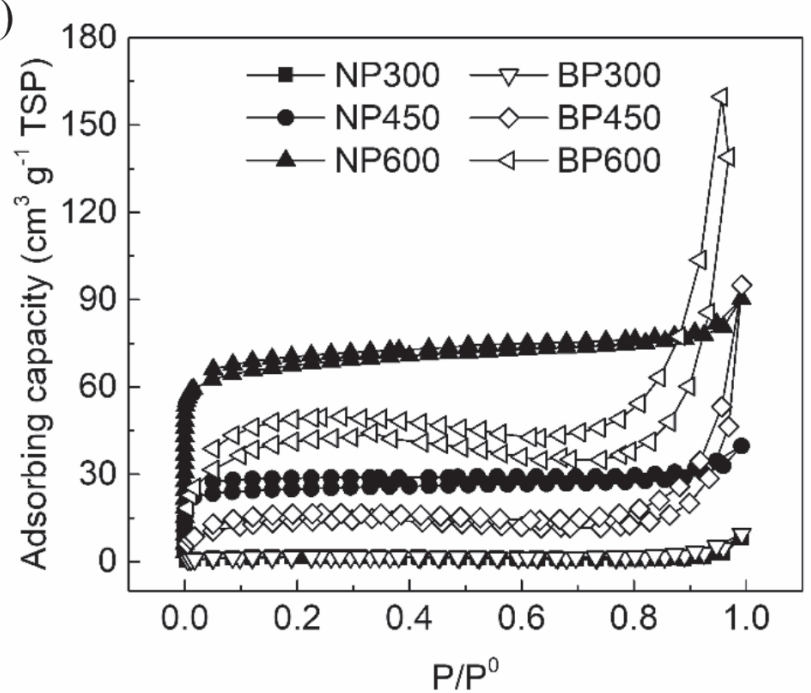

Fig. S1. Point of zero charge (PZC) a) and $\mathrm{N}_{2}$ adsorption-desorption isotherms b) of biochars. 

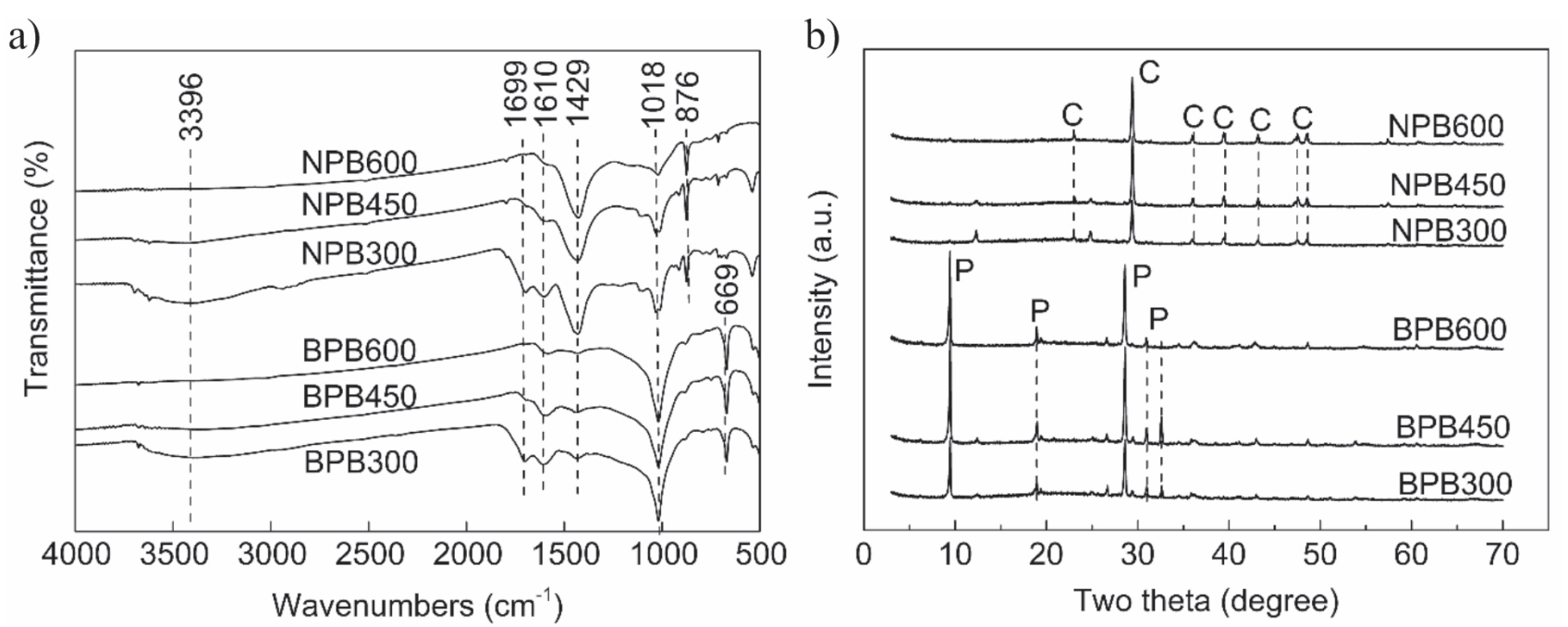

Fig. S2. FTIR spectra of bochars a) and XRD spectra of biochars b) (C refer to calcite, P refer to pyrophyllite).

a)

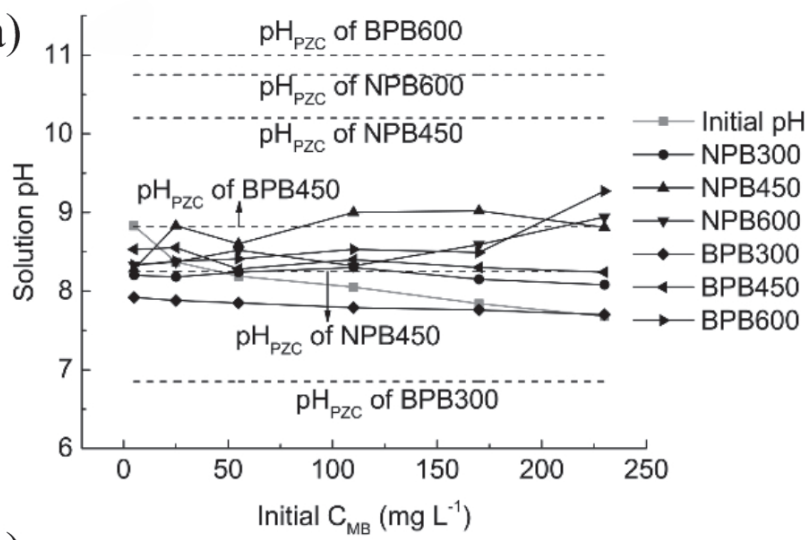

c)

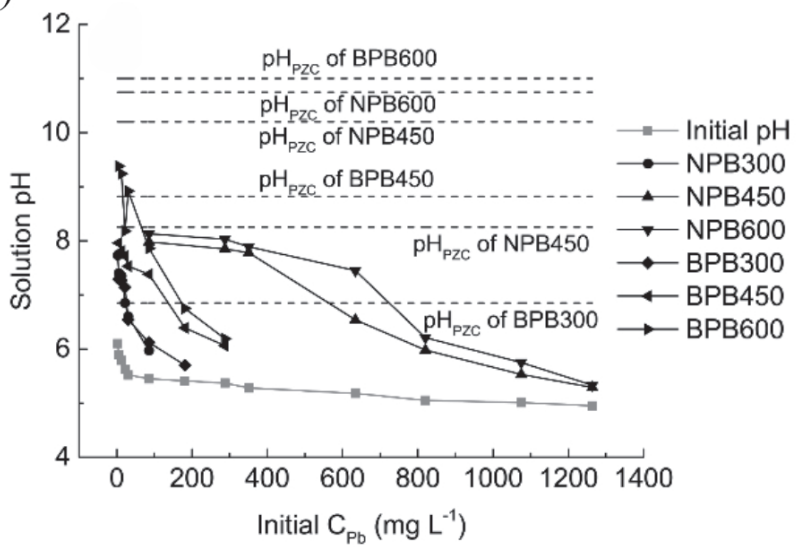

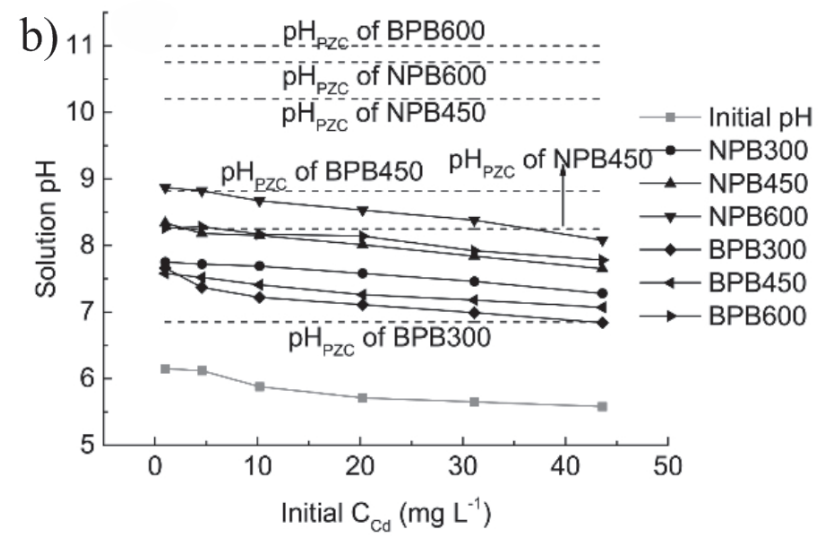

Fig. S3. Final $\mathrm{pH}$ values of the solutions in the sorption of $\mathrm{MB}$ a), $\mathrm{Cd}(\mathrm{II}) \mathrm{b}$ ) and $\mathrm{Pb}(\mathrm{II}) \mathrm{c}$ ). 


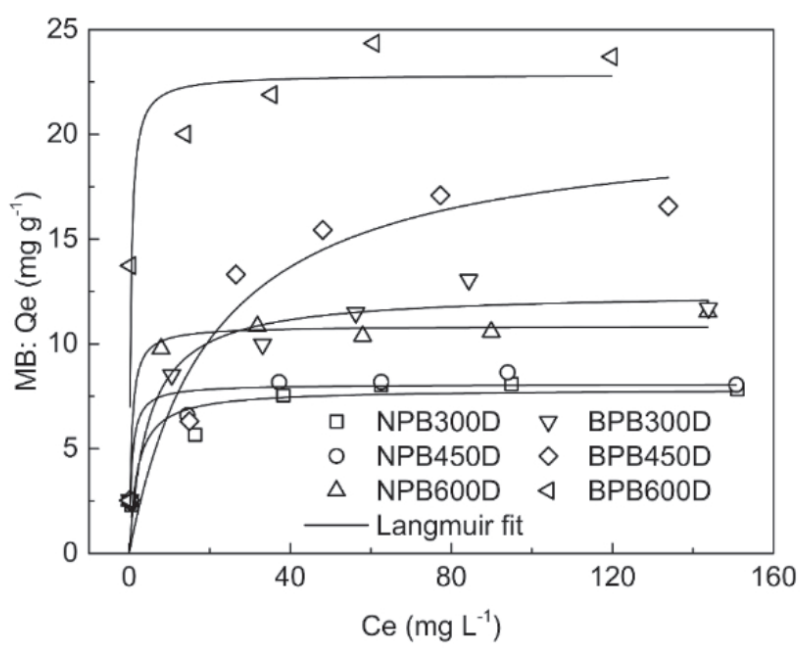

Fig. S4. MB adsorbed using de-ashed biochar.

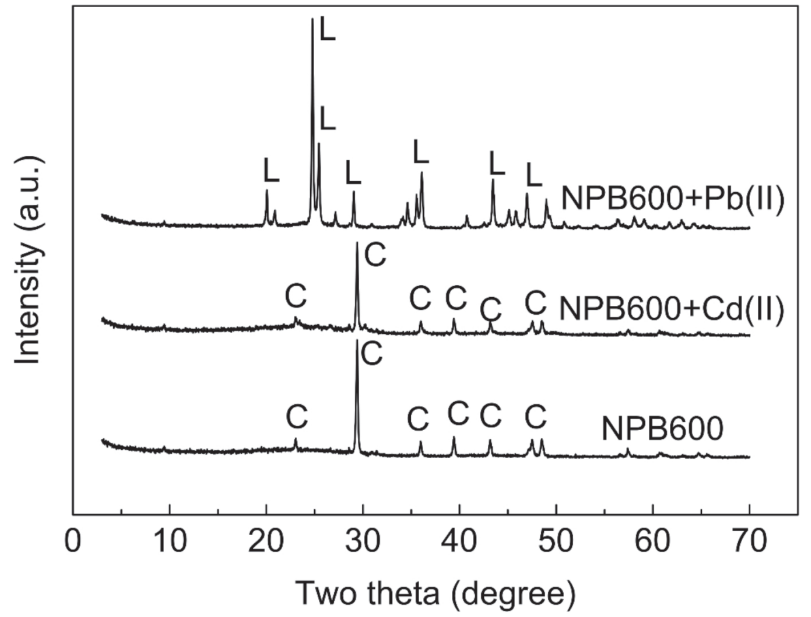

Fig. S5. XRD pattern of biochar after sorption (C refer to calcite, $\mathrm{L}$ refer to cerussite).
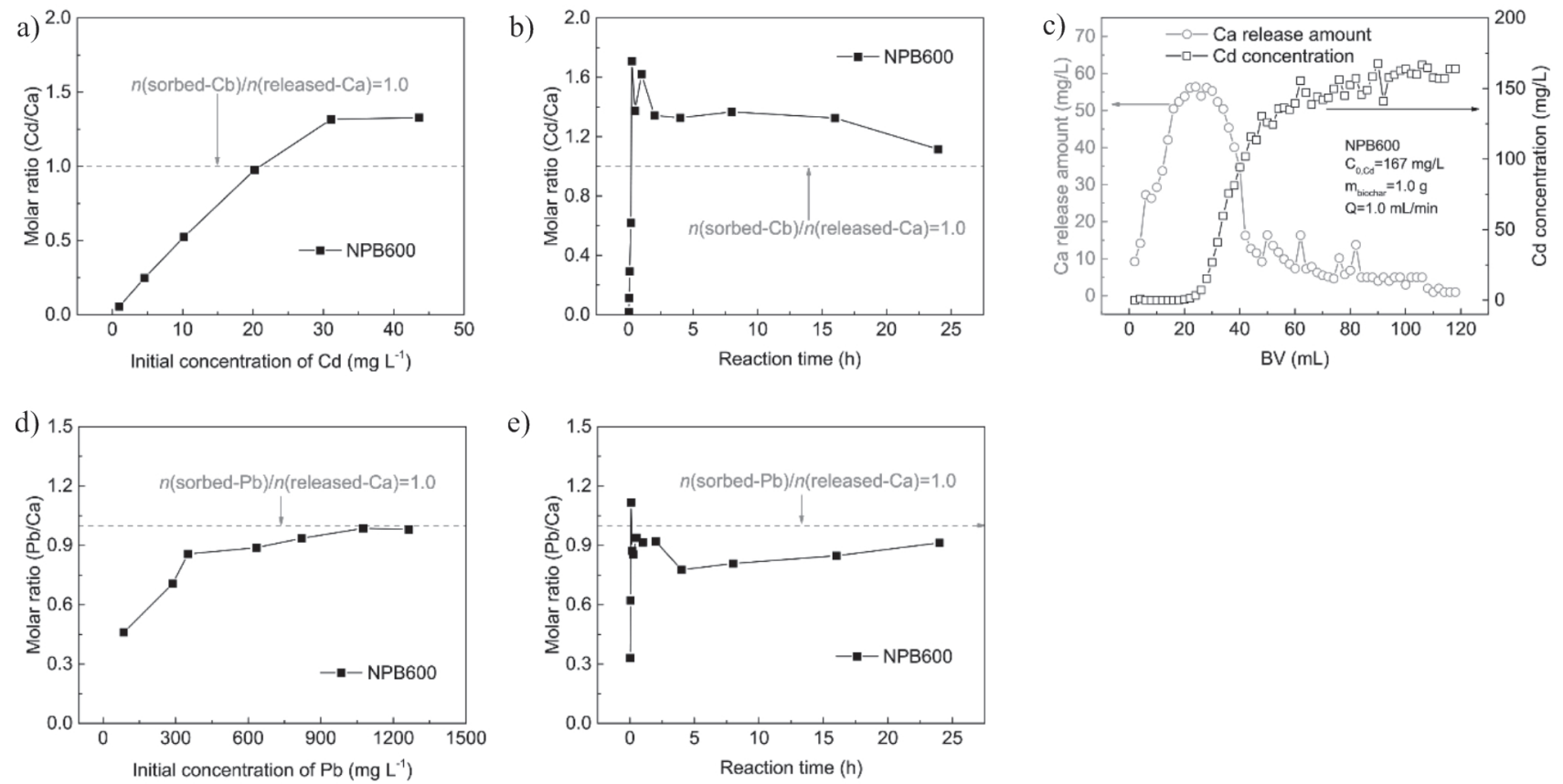

Fig. S6. Ca released during batch and column experiments. a) Molar ratio of sorbed-Cd and released-Ca as a function of initial $\mathrm{Cd}(\mathrm{II})$ concentration, b) Molar ratio of sorbed-Cd and released-Ca as a function of reaction time, c) $\mathrm{Ca}(\mathrm{II})$ release amount and $\mathrm{Cd}(\mathrm{II})$ concentration in solution during fixed-bed column sorption. f) Molar ratio of sorbed- $\mathrm{Pb}$ and released-Ca as a function of initial $\mathrm{Pb}(\mathrm{II})$ concentration, $\mathrm{g}$ ) Molar ratio of sorbed- $\mathrm{Pb}$ and released-Ca as a function of reaction time.

\section{References}

1. ZHANG C., SHAN B., TANG W., ZHU Y. Comparison of cadmium and lead sorption by Phyllostachys pubescens biochar produced under a low-oxygen pyrolysis atmosphere. Bioresource Technology 238, 352, 2017.

2. IFTHIKAR J., WANG J., WANG Q., WANG T., WANG H., KHAN A., JAWAD A., SUN T., JIAO X., CHEN Z. Highly efficient lead distribution by magnetic sewage sludge biochar: Sorption mechanisms and bench applications. Bioresource Technology 238, 399, 2017.

3. ZHANG T., ZHU X., SHI L., LI J., LI S., Lü J., LI Y.
Efficient removal of lead from solution by celery-derived biochars rich in alkaline minerals. Bioresource Technology 235, 185, 2017.

4. ZHOU N., CHEN H., XI J., YAO D., ZHOU Z., TIAN Y., LU X. Biochars with excellent $\mathrm{Pb}$ (II) adsorption property produced from fresh and dehydrated banana peels via hydrothermal carbonization. Bioresource Technology 232, 204, 2017.

5. WANG H., GAO B., WANG S., FANG J., XUE Y., YANG $\mathrm{K}$. Removal of $\mathrm{Pb}$ (II), $\mathrm{Cu}$ (II), and $\mathrm{Cd}$ (II) from aqueous solutions by biochar derived from $\mathrm{KMnO}_{4}$ treated hickory wood. Bioresource Technology 197, 356, 2015. 
6. ABDELHAFEZ A.A., LI J. Removal of $\mathrm{Pb}(\mathrm{II})$ from aqueous solution by using biochars derived from sugar cane bagasse and orange peel. Journal of the Taiwan Institute of Chemical Engineers 61, 367, 2016.

7. DING Z., HU X., WAN Y., WANG S., GAO B. Removal of lead, copper, cadmium, zinc, and nickel from aqueous solutions by alkali-modified biochar: Batch and column tests. Journal of Industrial and Engineering Chemistry 33, 239, 2016.

8. DENG X., Lü L., LI H., LUO F. The adsorption properties of $\mathrm{Pb}(\mathrm{II})$ and $\mathrm{Cd}(\mathrm{II})$ on functionalized graphene prepared by electrolysis method. Journal of Hazardous Materials 183, 923, 2010.

9. CATALDO S., GIANGUZZA A., MILEA D., MURATORE N., PETTIGNANO A. Pb(II) adsorption by a novel activated carbon-alginate composite material. A kinetic and equilibrium study. International Journal of Biological Macromolecules 92, 769, 2016.

10. LI Z., CHEN J., GE Y. Removal of lead ion and oil droplet from aqueous solution by lignin-grafted carbon nanotubes. Chemical Engineering Journal 308, 809, 2017. 